\title{
PENGEMBANGAN MEDIA KOMIK DIGITAL BERBASIS KONTEKSTUAL MATERI NILAI_NILAI PANCASILA KELAS III SD
}

\author{
Nabiilatudzakiyah \\ PGSD FIP Universitas Negeri Jakarta \\ nabiilazakiyah99@gmail.com
}

\begin{abstract}
The values of Pancasila are very important lesson to be instilled as early as possible to students so that they become intelligent and noble generations, but the use of learning media in this material is minimal Therefore, this study aims to produce a contextual based digital comic media that is feasible and valid to be used on Pancasila values material in grade III Elementary School and can make it easier for students to understand Pancasila values so that student can be apply them in everyday life. The method used in this research is Research and Development (R\&D) and uses the ADDIE model. The results of product development after validation bye expert and get the percentage of eligibility $91 \%$ form material experts and $96 \%$ from media experts. Then validated by 2 teachers and get a percentage of $96.4 \%$ eligibility. The digital comic learning media was tested for class III SDN 11 OKU. In the One to one evaluation stage, the percentage of feasibility is $92.4 \%$, in the small group evaluation stage, the percentage of feasibility is $93.2 \%$. Then at the Field evaluation stage, the percentage of feasibility is $86.04 \%$, meaning that contextual-based digital comic learning media material for grade III elementary school Pancasila values is very feasible for used and can make it easier for students to understand the material.
\end{abstract}

Keywords: Learning Media, Values Of Pancasila, Digital Comic, PPKn

\begin{abstract}
ABSTRAK
Nilai-nilai Pancasila merupakan materi yang sangat penting untuk ditanamkan sedini mungkin kepada siswa agar menjadi generasi yang cerdas dan berakhlak mulia, akan tetapi penggunaan media pembelajaran pada materi ini sangatlah minim. Oleh karena itu, penelitian ini bertujuan untuk menghasilkan media komik digital berbasis kontekstual yang layak dan valid untuk digunakan pada materi nilai-nilai Pancasila di kelas III SD serta dapat memudahkan siswa dalam memahami nilai-nilai Pancasila sehingga siswa dapat menerapkannya dalam kehidupan sehari-hari. Metode yang digunakan dalam penelitian yaitu Research and Development (R\&D) dan menggunakan model ADDIE. Hasil dari pengembangan produk setelah melakukan validasi oleh ahli dan mendapatkan persentase kelayakan $91 \%$ dari ahli materi dan $96 \%$ dari ahli media. Selanjutnya melakukan validasi oleh 2 guru dan mendapatkan persentase kelayakan $96.4 \%$. Media pembelajaran komik digital dilakukan uji coba kepada kelas III SDN 11
\end{abstract}


OKU. Pada tahapan One to one evaluation mendapatkan persentase kelayakan 92.44\% pada tahapan small group evaluation mendapatkan persentase kelayakan 93.2\% lalu pada tahapan Field evaluation mendapatkan persentase kelayakan $86.04 \%$ artinya, media pembelajaran komik digital berbasis kontekstual materi nilai-nilai Pancasila kelas III SD sangat layak untuk digunakan dan dapat memudahkan siswa dalam memahami materi.

Kata Kunci: Media Pembelajaran, Nilai-Nilai Pancasila, Komik Digital, PPKn

\section{A. Pendahuluan}

Pendidikan Pancasila dan Kewarganegaraan atau yang disingkat PPKn merupakan mata pelajaran yang sangat penting untuk membentuk peserta didik agar memiliki rasa cinta pada tanah air serta berakhlak baik sesuai dengan nilai-nilai Pancasila. Hal tersebut sesuai dengan pendapat menurut lubis (2020) yang menjelaskan bahwa PPKn memfokuskan pada pembentukan siswa agar memiliki jiwa yang Pancasilais serta membentuk siswa menjadi warga negara yang baik dan tidak melakukan perbuatan yang menyimpang.

Membahas tentang mata pelajaran maka tidak akan lepas kaitannya dengan pembelajaran. Menurut Azhar (2020) pembelajaran ialah kegiatan yang dapat memberikan informasi atau ilmu pengetahuan dan terdapat interaksi antara guru dan siswa di dalamnya, serta penggunaan alat saat pembelajaran yang sesuai dengan materi agar guru mudah untuk menyampaikan materi dan siswa dapat mudah memahaminya.

Akan tetapi penggunaan media pembelajaran pada mata pelajaran PPKn masih sangatlah minim, ditambah pembelajaran yang dilakukan dari jarak jauh disebabkan oleh pandemi yang melanda dunia. Sementara itu, mata pelajaran PPKn merupakan mata pelajaran yang sangat penting untuk penanaman nilai-nilai Pancasila kepada siswa. Berdasarkan dari wawancara yang dilakukan kepada wali kelas III SDN 11 OKU pada tanggal 28 April 2021 menjelaskan bahwa penggunaan media pembelajaran pada mata pelajaran PPKn masih sangatlah minim, saat pembelajaran dilakukan secara daring maka guru hanya membagikan video dari Youtube dan 
gambar melalui WhatsApp Group atau sebatas memberikan tugas dari buku tema.

Faktor yang menyebabkan guru merasa sulit untuk menggunakan media pembelajaran yang lain yaitu dikarenakan guru tidak sempat untuk membuat media pembelajaran yang lain serta guru merasa kesulitan untuk menggunakan teknologi sebagai media pembelajaran, sehingga menyebabkan siswa merasa jenuh saat pembelajaran. Hal tersebut sesuai dengan penelitian yang dilakukan oleh Eka Novita Pujiningtias, dkk (2019) yang menjelaskan alasan guru tidak mau menggunakan media pembelajaran dikarenakan merasa takut dan cemas dalam menghadapi perubahan dunia yang cepat sehingga menimbulkan perasaan tidak nyaman.

Berdasarkan dari permasalahan tersebut maka peneliti melakukan pengembangan media komik digital berbasis kontekstual materi nilai-nilai Pancasila kelas III SD. Menurut Fauzana (2020) pengertian Komik ialah media bergambar yang dilengkapi dengan balon kata yang berfungsi untuk mendeskripsikan cerita agar pembaca dapat memahami isi cerita tersebut. Komik merupakan bacaan yang digemari oleh berbagai kalangan terkhusus anak-anak, dan dengan semakin majunya teknologi saat ini komik digital semakin mudah diakses oleh siapapun serta lebih ekonomis, sesuai dengan penelitian yang dilakukan oleh Anissa Fitriana dan Irwansyah (2020) menjelaskan bahwa platform untuk membaca komik digital di Indonesia yaitu Line Webtoon memiliki 6 juta pengguna, adapun menurut Gideon Kamang Frederick (2020) yang memaparkan data dari platform membaca komik digital lainnya yaitu Ciayo Komik memiliki 150 juta pembaca di Indonesia, dan juga Indonesia memiliki website khusus untuk membaca komik digital pendidikan yang bernama Komik Pendidikan.id dan telah diakses sebanyak lebih dari 12 juta kali, hal ini menunjukkan bahwa minat membaca komik di Indonesia cukup tinggi maka dari itu peneliti mengembangkan komik digital sebagai media pembelajaran dikarenakan di dalam komik terdapat gambar yang dibuat secara menarik serta terdapat alur cerita yang menyenangkan, sehingga lebih mudah dipahami oleh siswa. Komik sebagai media pembelajaran pun 
dikarenakan adanya unsur visual dalam komik yang dapat menunjukkan objek dan situasi yang konkret dalam bentuk cerita. Hal tersebut sesuai dengan menurut Waluyanto (2015) bahwa komik digital sebagai media pembelajaran berfungsi untuk menyampaikan materi atau informasi secara jelas dan lebih mudah dipahami dikarenakan menggunakan gambar serta rangkaian tulisan yang membentuk sebuah alur cerita.

Komik yang dikembangkan merupakan komik digital yang mana dibentuk seperti flip book dan dapat disebarkan melalui link yang dikirimkan melalui WhatsApp Group. Komik pun dapat mudah diakses oleh seluruh siswa, dapat dibaca dimana saja dan kapan saja, sangat ekonomis dikarenakan tidak perlu mencetak komik, serta terdapat alunan musik di dalam komik sehingga membuat siswa tidak merasa jenuh saat pembelajaran.

Pembelajaran PPKn memiliki banyak sekali materi yang berhubungan langsung dengan kehidupan sehari-hari siswa, termasuk materi nilai-nilai Pancasila, maka dari itu pendekatan yang digunakan pada komik ini ialah kontekstual yang mana menurut Sears (2018) pendekatan kontekstual ialah suatu pendekatan yang mengaitkan materi dengan situasi nyata sehingga memberikan motivasi pada siswa untuk terlibat dalam proses pembelajaran dan membangun ikatan antara ilmu pengetahuan yang didapat dengan pengaplikasiannya dalam kehidupan. Hal tersebut sesuai dengan pendapat menurut Piaget (2017) bahwa perkembangan kognitif siswa sekolah dasar memasuki tahapan operasional konkrit yang mana siswa masih belum bisa berpikir secara abstrak akan tetapi sudah dapat berpikir secara logis dan rasional walaupun terbatas pada objek dan situasi yang konkret. Maka dari itu, dengan menggunakan

pendekatan kontekstual pada komik sangatlah sesuai dengan perkembangan kognitif siswa kelas III SD. Media tersebut diharapkan dapat menjadi media yang layak digunakan serta dapat membantu siswa dalam memahami materi nilai-nilai Pancasila, membantu guru dalam menyampaikan materi nilai-nilai Pancasila serta menjadi ide baru untuk para guru dalam penggunaan 
media pembelajaran yang lebih kreatif.

\section{B. Metode Penelitian}

Metode yang digunakan dalam penelitian ialah metode Research and Development (R\&D) yang mana menurut Borg\&Gall menjelaskan penelitian R\&D ialah suatu metode yang digunakan untuk pengembangan dan validasi suatu produk pendidikan. Model yang digunakan dalam penelitian ini ialah model ADDIE, dalam model ini terdapat 5 tahapan akan tetapi peneliti membatasi hingga tahapan ke 4 diantara nya ialah Analysis, Design, Development dan Implementation. Produk yang dihasilkan dari penelitian ini ialah media komik digital berbasis kontekstual materi nilai-nilai Pancasila kelas III SD. Penelitian dilaksanakan di SDN 11 OKU Baturaja Timur, dengan subyek penelitian yaitu kelas III SDN 11 OKU. Teknik pengumpulan data yang digunakan yaitu wawancara, angket, lembar validasi yang berikan kepada ahli materi, ahli media, dan 2 orang pendidik, serta angket respon siswa mengenai komik digital.
Teknik analisis data yang digunakan untuk mengetahui kelayakan media yaitu menggunakan deskriptif kualitatif pada analisis kebutuhan dan kuantitatif pada angket validasi, adapun pada angket validasi menggunakan skala likert sebagai pengukuran penelitian pengembangan Berikut ialah tabel skoring pada skala likert:

Tabel 1. Skoring Pada Skala Likert

\begin{tabular}{cc}
\hline Kategori & Skor Item \\
\hline Sangat Setuju & 5 \\
\hline Setuju & 4 \\
\hline Cukup & 3 \\
\hline Tidak Setuju & 2 \\
\hline Sangat Tidak Setuju & 1 \\
\hline
\end{tabular}

Setelah mendapatkan data dari ahli materi, ahli media, pendidik, serta peserta didik, maka dilakukan perhitungan skor dengan menggunakan rumus dibawah ini:

Persentase

$=\frac{\text { Jumlah Skor Yang Diperoleh }}{\text { Jumlah Skor Maksimal }} \times 100$ Hasil dari perhitungan menggunakan rumus diatas maka peneliti menghitung kelayakan dari produk yang dikembangkan dibagikan berdasarkan kategori berikut:

Tabel 2 Penilaian Kelayakan Produk 


\begin{tabular}{cc}
\hline Tingkat Pencapaian & Klasifikasi \\
\hline $81 \%-100 \%$ & Sangat Layak \\
\hline $61 \%-80 \%$ & Layak \\
\hline $41 \%-60 \%$ & Cukup Layak \\
\hline $21 \%-40 \%$ & Tidak Layak \\
\hline $0 \%-20 \%$ & Sangat Tidak Layak \\
\hline
\end{tabular}

\section{Hasil Penelitian dan}

\section{Pembahasan}

Media yang dikembangkan merupakan media komik digital berbasis kontekstual materi nilai-nilai Pancasila kelas III SD yang mana alur cerita dalam komik tersebut diangkat dari tema 8 (Praja Muda Karana). Peneliti menggunakan media komik digital untuk materi ini diharapkan dapat menambah pengalaman siswa dalam menggunakan media pembelajaran komik digital serta memudahkan siswa dalam memahami materi nilainilai Pancasila.

Hal yang menjadi ciri khas dalam komik ini ialah komik dibuat dalam bentuk flip book sehingga saat membaca komik tersebut siswa dapat merasa seperti membaca buku yang sebenarnya. Penyebaran komik yang menggunakan link sangat memudahkan siswa dan guru dalam mengakses komik tersebut, serta terdapat musik di dalam komik yang menjadikan komik tidak bosan dan memberikan efek menyenangkan saat dibaca. Komik didesain awal secara manual terlebih dahulu sebelum diwarnai secara digital dengan aplikasi Medibang Paint dan diberi balon percakapan sesuai alur cerita, setelah itu komik dibuat berbentuk flip book dengan menggunakan website FLIPHTML5.

Hasil produk yang telah dikembangkan ialah sebagai berikut:
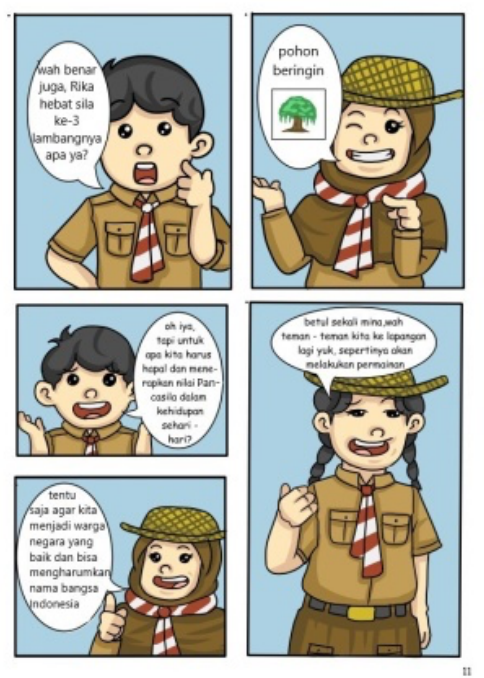

Gambar 1 Hasil Produk Akhir
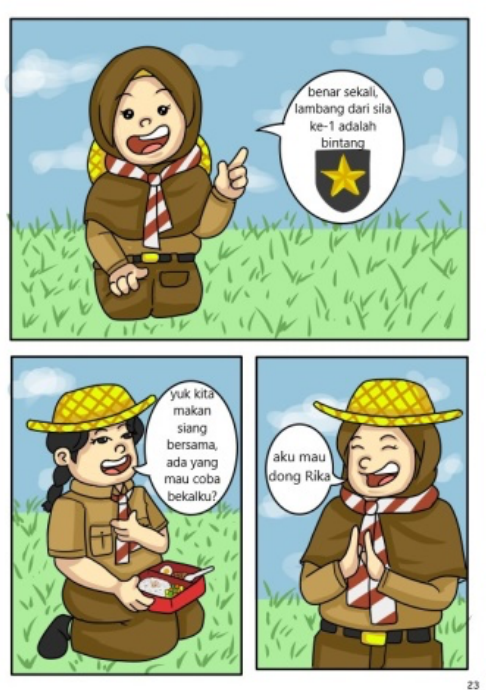
Gambar 2 Hasil Produk Akhir

Produk komik digital dikembangkan berdasarkan dari hasil validasi yang dilakukan oleh para validator. Terdapat dua validator yaitu ahli media dilakukan untuk menilai apakah produk yang dikembangkan layak berdasarkan dari segi media. Aspek penilaian yang terdapat dalam angket ahli media yaitu meliputi tampilan, penyajian, bahasa dan media. Serta validator ahli materi untuk menilai apakah produk yang dikembangkan layak berdasarkan dari ahli materi. Aspek penilaian dalam angket ahli materi meliputi pembelajaran, bahasa, materi, dan penyajian. Setelah melakukan validasi dari dua ahli, setelah itu melakukan validasi dari dua pendidik yang merupakan wali kelas III A dan III $D$, dalam angket meliputi aspek penilaian yaitu kurikulum, penyajian, bahasa, materi, penggunaan media. Setelah melakukan validasi, produk pun diuji coba kepada peserta didik dengan menyebarkan angket yang memiliki aspek penilaian penyajian, bahasa, materi, dan penggunaan media. Setelah mendapatkan hasil dari angket peneliti pun melakukan analisis data dengan deskriptif kuantitatif.

Hasil dari validasi produk komik digital mendapatkan mendapatkan persentase kelayakan sebesar $96 \%$ dengan kategori sangat layak yang mana tidak diperlukan revisi terhadap produk dari ahli media yang merupakan dosen Pendidikan Guru Sekolah Dasar. Adapun validasi dari ahli materi yang merupakan dosen Pendidikan Pancasila dan Kewarganegaraan mendapatkan persentase kelayakan sebesar $91 \%$ dengan kategori sangat layak dengan beberapa perbaikan pada komik digital.

Setelah dilakukan validasi oleh dua ahli, peneliti melakukan angket penilaian dari 2 guru SDN 11 OKU dan mendapatkan persentase kelayakan sebesar 96,4\% dengan kategori sangat layak dan tidak diperlukan revisi.

Selanjutnya melakukan validasi, peneliti pun membagikan angket respon siswa terhadap komik digital dalam 3 tahap, tahap pertama yaitu tahap one to one evaluation yang melibatkan 3 siswa dari kelas III SDN 11 OKU, dan mendapatkan persentase kelayakan sebesar $92,44 \%$ dengan kategori sangat 
layak, tahap kedua yaitu small group evaluation yang melibatkan 10 siswa kelas III SDN 11 OKU dan medapatkan persentase kelayakan sebesar 93,2\% dengan kategori sangat layak, dan tahap terakhir yaitu field evaluation yang melibatkan 30 siswa kelas III SDN 11 OKU dan mendapatkan persentase kelayakan sebesar $86,04 \%$ dengan kategori sangat layak.

Adapun berdasarkan dari masukan serta saran dari siswa yang mana penggunaan media pembelajaran membuat siswa lebih mudah dalam memahami materi, serta sangat menarik untuk siswa membuat siswa lebih bersemangat saat belajar. Hal tersebut sesuai dengan fungsi dari penggunaan media pembelajaran yang dikemukakan oleh Benni Agus Pribadi (2019) media pembelajaran untuk membantu siswa saat proses pembelajaran serta memberikan gambaran secara nyata agar lebih mudah dipahami oleh siswa. Adapun juga siswa merasa lebih bersemangat saat pembelajaran dan mendapatkan pemahaman baru selain dari buku pelajaran, hal tersebut sesuai dengan apa yang dipaparkan oleh Nana Sudjana dkk (2020) bahwa manfaat dari media pembelajaran yaitu dapat meningkatkan motivasi siswa saat proses pembelajaran dikarenakan pembelajaran berlangsung dengan menarik dan menyenangkan bagi siswa. Alur cerita dalam komik pun disesuaikan dengan tema serta menggunakan basis kontekstual yang mana penerapan nilai-nilai Pancasila sesuai dengan kejadian nyata dalam kehidupan sehari-hari siswa. Hal tersebut sesuai dengan menurut US Departement of Education (2018) bahwa pendekatan kontekstual merupakan proses pembelajaran yang mana mengaitkan materi pelajaran dengan situasi yang nyata serta membantu siswa untuk menghubungkan pengetahuan yang telah dipelajarinya dengan penerapan di kehidupan sehari-harinya.

Keunggulan pada komik digital ini ialah komik dapat dibaca dimana saja, kapan saja serta dapat diakses oleh siapa saja dengan menekan link yang telah dibagikan, gambar pada komik dan pemilihan warna yang menarik serta memiliki alur cerita dibuat sesuai dengan tema 8 yaitu "Praja Muda Karana" yang mana terdapat materi nilai-nilai Pancasila di dalamnya, komik disertai dengan alunan musik yang menyenangkan 
agar siswa tidak merasa bosan saat membaca komik, dengan komik digital pun tidak diperlukan untuk mencetak komik sehingga sangat ekonomis. Kendala yang terdapat dalam media komik ini diperlukan sinyal yang stabil, sehingga untuk siswa yang berada di tempat yang sulit sinyal merasa kesulitan untuk mengakses komik.

Oleh karena itu, berdasarkan dari hasil uji coba diatas maka dapat disimpulkan bahwa komik digital sangat layak untuk digunakan sebagai media pembelajaran materi nilai-nilai Pancasila kelas III SD dan juga sangat memudahkan siswa dalam memahami materi.

\section{E. Kesimpulan}

Media komik digital berbasis kontekstual materi nilai-nilai Pancasila menggunakan metode Research \& Development (R\&D) dan model ADDIE dengan tahapan yang dilakukan yaitu analysis, design, development, implementation.

Komik digital mendapatkan persentase kelayakan dari ahli materi yaitu sebesar $91 \%$ dan dari ahli media sebesar 96\%. Dari hasil angket yang diberikan kepada 2 guru mendapatkan persentase kelayakan sebesar $96,4 \%$.

Pada uji coba kepada peserta didik dilakukan sebanyak 3 tahapan, pada tahapan pertama yaitu one to one evaluation komik digital mendapatkan persentase kelayakan sebesar 92,44\%, tahapan kedua yaitu small group evaluation mendapatkan persentase kelayakan sebesar $93,2 \%$, tahapan ketiga yaitu field evaluation mendapatkan persentase kelayakan sebesar 86,04\%.

Berdasarkan dari hasil persentase yang didapatkan sebelumnya maka dapat dinyatakan bahwa media komik digital berbasis kontekstual materi nilai-nilai Pancasila kelas III SD sangat layak untuk digunakan.

\section{DAFTAR PUSTAKA}

Darmawan, Daddy, \& Cecep Kustandi. (2020). Pengembangan Media Pembelajaran. Jakarta: KENCANA.

Frederick, Gideon Kamang. (2020). Komik Di Media Sosial Dalam Narasi Entrepreneurship Dan Ekonomi Kreatif Di Indonesia. Jurnal Komunikasi Visual, 59-64

Heru Muslim, Aji, dkk. (2020). Media Pembelajaran PKn Di SD. Banyumas: CV. Pena Persada. 
Kusumawati, Naniek, \& Vivi Rulviana. (2017). Pengembangan Kurikulum Di Sekolah Dasar. Magetan: CV. Media Grafika.

Lestari, Annisa Fitriana, \& Irwansyah. (2020). Line Webtoon Sebagai Industri Komik Digital. Jurnal IImu Komunikasi, 134-148.

Lubis, Maulana Arafat. (2020). Pembelajaran Pendidikan Pancasila Dan Kewarganegaraan Di SD/MI. Jakarta: Kencana.

Nurdiyansyah. (2019). Media Pembelajaran Inovatif. Sidoarjo: UMSIDA Press.

Pohan Efendi, Albert. (2020). Konsep Pembelajaran Daring Berbasis IImiah. Purwodadi: CV Sarnu Untung.

Pujianingtias, Eka Novita, dkk. (2019). Pengembangan Media Majamat Pada Materi Pecahan Pada Mata Pelajaran Matematika. Jurnal Penelitian dan Pengembangan Pendidikan, 257.

Rahman, Taufiqur. (2018). Aplikasi Model-Model Pembelajaran Dalam Penelitian Tindakan Kelas. Semarang: CV. Pilar Nusantara.

Setyosari, Punaji. (2020). Desain Pembelajaran. Jakarta: PT. Bumi Aksara.

Trianingsih, Rima. (2018). Aplikasi Pembelajaran Kontekstual Sekolah Dasar Abad 21. Banyuwangi: LPPM IAI Ibrahimy Genteng Press.

Widyawati, Ani, \& Anti Kolonial Prodjosantoso. (2015).
Pengembangan Media Komik IPA Untuk Meningkatkan Motivasi Belajar Dan Karakter Peserta Didik Smp. Jurnal Inovasi Pendidikan IPA, 24. 